\title{
Policing consumer contracts in China and the EU
}

\author{
Citation for published version (APA):
}

Ge, J. (2017). Policing consumer contracts in China and the EU: A comparative analysis. [Doctoral Thesis, Maastricht University]. Datawyse / Universitaire Pers Maastricht. https://doi.org/10.26481/dis.20171107gj

Document status and date:

Published: 01/01/2017

DOI:

10.26481/dis.20171107gj

Document Version:

Publisher's PDF, also known as Version of record

\section{Please check the document version of this publication:}

- A submitted manuscript is the version of the article upon submission and before peer-review. There can be important differences between the submitted version and the official published version of record.

People interested in the research are advised to contact the author for the final version of the publication, or visit the DOI to the publisher's website.

- The final author version and the galley proof are versions of the publication after peer review.

- The final published version features the final layout of the paper including the volume, issue and page numbers.

Link to publication

\footnotetext{
General rights rights.

- You may freely distribute the URL identifying the publication in the public portal. please follow below link for the End User Agreement:

www.umlib.nl/taverne-license

Take down policy

If you believe that this document breaches copyright please contact us at:

repository@maastrichtuniversity.nl

providing details and we will investigate your claim.
}

Copyright and moral rights for the publications made accessible in the public portal are retained by the authors and/or other copyright owners and it is a condition of accessing publications that users recognise and abide by the legal requirements associated with these

- Users may download and print one copy of any publication from the public portal for the purpose of private study or research.

- You may not further distribute the material or use it for any profit-making activity or commercial gain

If the publication is distributed under the terms of Article $25 \mathrm{fa}$ of the Dutch Copyright Act, indicated by the "Taverne" license above, 
This study is about the legal rules on policing consumer contracts in two jurisdictions: China and the EU. It aims to fill a gap in the existing literature, by describing the formulation, interpretation and enforcement of these rules, and mapping similarities and differences. However, this study does not address all issues regarding consumer contracts. Sources of law in China and the EU are first discussed to set the scene. Afterwards, one preliminary issue, how to define the concept of a consumer contract, and two substantive topics, unfair terms and withdrawal rights, are dealt. Apart from the descriptive analysis, this study also tries to provide possible explanations for these comparative findings. Four research hypotheses underlie the research conducted. These hypotheses are based on the presumption that the existence of differences in consumer contract rules can be primarily attributed to a disparity of markets. These hypotheses are tested on the basis of the comparative outcomes; the results constitute the conclusions of this study.

This study consists of six chapters. Chapter 1 first presents the background of this study. Two core research questions and five sub-questions are then proposed. The research hypotheses that are raised afterwards are the essence of this chapter. It is presumed that China has a more regulated market; it has a lower level of demand for consumer law rules, and the level of requirement for the clarity and concreteness of these rules is also lower; the criteria employed by its consumer law on assessing misconduct are more substantive; its consumer law puts more emphasis on consumer protection than consumer information; and it focuses on the public enforcement of consumer law. On the contrary, the EU has a more competitive market; it has a higher level of demand for consumer law rules; the criteria on assessing misconduct are more procedural; its consumer law inclines to provide consumers with sufficient information; and it focuses more on private enforcement. Chapter 1 also provides an overview of how the methodology of comparative approach works in this study, the structure of the study, this study's academic value, its societal relevance and limits.

Chapter 2 intends to answer the question what are the sources of law in China and the EU. It is pointed out that in China the statutes and their interpretations are the sources which should be analysed. In EU law, the most important sources in this study's context are EU-directives. Although in both jurisdictions the courts play an essential role in setting substantive rights and obligations, the Chinese Supreme People's Court usually targets to supplement the existing law which has been promulgated 
for a long period, whilst the CJEU in many cases acts at an earlier stage to provide clarifications for national legislators and judges.

Chapter 3 discusses the definition and the requirements of a consumer contract, to which the specifically designed consumer protection rules are applicable, in order to set the scope of the type of contract under scrutiny in this study. For the definition of 'consumer', the EU definition clarifies that the consumer has to be a natural person who acts outside his trade, business or profession, whilst in China it has not been elaborated whether only a natural person can be identified as a consumer. It is only required that the consumption has to be a daily one. For the 'trader', the EU definition still focuses on 'trader, business and profession', whilst the Chinese definition is much vaguer and only mentions providing commodities and services. In addition, some specific groups are treated differently in the EU and China. For example, farmers are consumers in China, but not in the EU. On the basis of the comparison of Chinese and EU rules, Chapter 3 points out that the major difference in the context of the concept of consumer contract between China and the EU is the level of clarity, which may be explained by the hypothesis raised in Chapter 1 .

Chapter 4 addresses the first substantive topic: unfair terms. In the EU and China, the approaches to assess standard terms and the legal consequences are rather similar. In both jurisdictions, the emphasis lies on two parts: the process of negotiation and conclusion of the contract (formal control) and the substantive definition of rights and obligations (substantive control). The former requires the user of standard terms to provide the consumer with an actual opportunity to become acquainted with the terms and agree to them. It also requires the judge or the administrator to adopt the interpretation against the user when the term is ambiguous. The latter also includes two steps: the general criteria that apply to all circumstances and the lists that provide the examples of unfair terms. For the general criteria, legislators in different jurisdictions usually use abstract concepts or principles such as 'fairness' and 'good faith', whilst for the lists attention is paid to whether the allocation of rights and obligations creates an imbalance which is prohibited by law.

Apart from the similarities, two significant differences can be found. Firstly, on the one hand, procedural elements play a much more important role in the EU approach. The requirement of transparency not only constitutes part of the formal control, but also supplements the substantive control. On the other hand, the significance of substantive element is decreased, because the exclusion of core terms makes it impossible to assess the most substantive part of the contract. In China, neither the exclusion of core terms nor procedural elements can be found. Secondly, the Chinese administrative bodies play a more significant role than their European counterparts (Germany and England in this study's context) when enforcing rules on unfair terms. The administrations for industry and commerce can be the final evaluator of the fairness test and use powerful means, such as the imposition of a fine and administrative sanctions, to strike down unfair terms. These two differences may also be explained by the hypotheses proposed in Chapter 1.

Chapter 5 discusses the second substantive topic: withdrawal rights. This chapter manifest that most of the components of the system of withdrawal rights in two juris- 
dictions are rather similar. The applicable scope, exceptions, lengths of periods, exercise of withdrawal rights, and legal consequences are both regulated in Chinese law and EU law. Nevertheless, two important differences are found. Firstly, the levels of the rules' certainty are different. In EU law, the applicable scope of withdrawal rights is not only determined by the semantic analysis of the abstract concepts such as 'distance contract' and 'off-premises contract', but also by the detailed definition of these concepts, which is also provided by the directive. By contrast, Chinese law only mentions several very specific patterns of transaction. No definition is provided, nor the guidance to interpret. This is also the case in the context of the exceptions to withdrawal rights: EU law provides more detailed examples, and no room is left for the national legislator or businesses to regulate their own standard. The second difference is the rules' orientation, compared with EU law, Chinese rules on withdrawal rights are more inclined to balance the interests of consumers and traders. The consumer's power is restrained, since the withdrawal period is shorter; traders can to some extent design their own criteria for exceptions; traders do not have to bear the cost of withdrawal transportation; consumers may lose their right when the commodity is damaged, even if it is caused by the normal inspection. For these two differences, the hypotheses put forward in Chapter 1 may explain the first difference. The second difference may be explained from the economic perspective that manufacturing and export play a significant role in the operation of Chinese socialist market economy.

Chapter 6 concludes by testing the research hypotheses on the basis of the comparative outcome, where the description and comparison of the relevant rules in Chinese law and EU law are summarised. The research results show that to some extent a more regulated market, which refers to China in this study, tends to have more obscure and abstract rules; when assessing misconduct, these rules focus on the substance; and public authorities play a significant role in enforcing these rules. A more competitive market, which refers to the EU in this study, tends to have consumer law rules which are more precise and detailed; procedural elements are emphasised when assessing misconduct; and in some specific markets, for instance Germany and England, the function of public authorities is limited compared to a regulated market. Chapter 6 also discusses the limits of this study and proposes recommendations for future research. 



\section{内容简介}

本书的研究对象是中国与欧盟两大法域与消费者合同效力相关的法律规则。 它旨在通过描述这些规则的文本表达、解释适用以及落实方式, 并总结不同 法域规则之异同, 来填补目前学术研究中的空白地带。然而, 本书并非讨论 与消费者合同相关的一切事宜。本书首先讨论了中国与欧盟消费者合同法的 法源, 继而深入研究了一个前提性问题——消费者合同的定义, 及两个实质 性问题——不公平条款与消费者反悔权。除了描述性研究之外, 本书亦旨在 为上述总结出的异同提供可能的解释思路。为此, 本书提出了四项假设, 而 这些假设均基于同一出发点, 即消费者合同规则中的不同, 主要应归结于不 同市场之间的差异。本书利用比较两大法域规则所得出的成果来验证上述假 设, 获得的结论即为最终的研究成果。

本书包括六章。第一章介绍了研究背景, 提出了两大核心研究问题和五个 子问题。如前所述, 研究假设是本章最为重要的内容。本书将市场区分为管 制型市场和竞争型市场两大类，并指出中国市场与欧盟市场相比属于前者。 由此，中国消费者合同法中的规则可能存在如下特征：与欧盟相比，首先， 对于规则的需求程度偏低, 且往往会采取更加灵活、模糊的立法技术; 其次, 在评价经营者的不当行为时, 消费者合同规则采取的判断标准往往更加实质; 第三，规则的内容更注重保护消费者固有的人身和财产权利，而非提供消费 者足够信息、帮助他们做出合理选择; 第四, 消费者合同法更注重依托于政 府的“公力执行”。相较之下, 欧盟市场与中国相比属竞争市场, 它的消费者合 同法可能存在如下特征：首先，市场对于清晰、明确的消费者合同法有较高 需求; 其次, 评价不当行为时采取的判断标准更加注重程序性要素; 第三, 相较于保护消费者固有的财产和人身权利，规则更注重提供消费者充足信息; 第四，法律的落实更依托于消费者个体的“私力执行”。除上述研究假设外，第 一章还介绍了本书应用比较研究的方法、本书的结构、学术价值、社会效用 以及局限性。

第二章试图回答如下问题: 中国与欧盟消费者合同法的法源有哪些。本书 认为, 中国的法律和司法解释是本书需要重点分析的对象; 在研究欧盟法时, 则应把研究重心放在欧盟指令上。此外, 尽管中国最高人民法院和欧盟法院在 
创设规则、为当事人设置实质意义上的权利义务这一方面均扮演了重要角色， 前者一般着眼于为已经施行了较长一段时间的立法进行补充, 而后者则往往在 立法出台不久就需要为成员国的立法者和法官提供说明和澄清。

第三章讨论了消费者合同的定义和构成要件, 以说明中欧消费者合同法的 适用范围。对于“消费者”来说，欧盟法所提供的定义要求消费者须为自然人. 且其行为须无关于贸易、商业及职业目的。在中国, 法律并未明确消费者是 否只能是自然人，仅仅指出消费须为生活之目的。对于 “经营者”来说，欧盟 法所提供的定义仍然着眼于贸易、商业及职业, 而中国法对经营者的定义更 加模糊, 只是提到了提供商品和服务。此外, 某些特定人群在中国法和欧盟 法上可能待遇不同。比如说, 农民在中国属于消费者, 在欧盟则不然。在比 较了中国法和欧盟法规则之后, 本书指出, 两者最大的不同是在规则的明确 程度上, 这在一定程度上可以被本书第一章所提出的研究假设所解释。

第四章讨论了本书的第一个实质性主题: 不公平条款。本书指出, 在欧盟 和中国, 评价不公平条款的方法和其法律效果是非常相近的。在这两个法域, 评价合同条款的着眼点都被放在了如下两个方面: 合同碰商与订立的过程（形 式控制), 及实质性的权利义务分配 (实质控制)。前者要求格式条款的使用者 为消费者提供真正了解合同条款、并且对条款订入表示同意的机会, 同时亦要 求法官或相关行政人员在条款含义模糊时作不利于条款使用人的解释。后者则 同样包括两部分：适用于所有情形的一般标准，以及不公平条款的示例清单。 对于一般标准来说, 中国与欧盟的立法者往往会使用类似于 “公平”、“诚实信 用”这样的抽象概念。而就示例清单而言, 立法者的关注焦点则主要集中于那 些权利义务分配失衡、且该失衡不能被法律所允许的合同条款。

除相同点之外, 中国与欧盟关于规制不公平条款的法律规则也有两大不 同。首先, 程序性因素在欧盟法中扮演了更为重要的角色。透明性原则不仅 是形式控制的核心组成部分, 在实质控制中也是重要的辅助判断标准。与此 同时, 实质性要素的弱化也体现在合同的核心条款无须被审查, 这导致法律 规则无法评价合同中最实质的部分。在中国, 上述程序性因素并未在立法中 得到体现, 核心条款的排除适用也未见踪影。其次, 中国的行政机关在执行 不公平条款相关规则的活动中起到了比德国、英国等欧盟国家的行政机关更 为关键的作用。中国的工商管理部门可以是格式条款效力的终局判断者, 也 可以使用各种强有力的手段 比如罚款和其他行政制裁 来打击不公平 条款。这两大不同均可以通过本书第一章所提出的假设来解释。

第五章乃关于本书所探讨的第二个实质性主题: 消费者反悔权。本书指出, 中国与欧盟法所规定的该项权利在大部分内容上具有相似性, 如两者都规定 了该权利的适用范围、例外情形、期间长度、行使方式和法律效果。不过, 仍有两大不同值得注意。其一, 规则的明确程度有差异。比如说, 就反悔权 的适用范围而言, 欧盟法并非仅仅是规定抽象概念——像“远距离合同”、“商 铺外合同”这些, 在相关欧盟指令中都有明确、详细的定义说明。相较之下, 
中国法只是罗列了几种具体的交易形式。立法既没有给出具体定义, 也没有 给出可供参考的解释说明。在反悔权例外情形的规定过程中, 也同样存在该 现象。欧盟法所给出的例外清单更为详细, 成员国立法和商家很难在此基础 上再额外设置权利的行使限制。中国法则相反。其二, 规则的导向有差异。 与欧盟法相比, 中国法对于反悔权的规定更注重平衡消费者与经营者间的利 益关系。这体现在如下方面: 中国消费者的权利行使期间更短; 经营者在一 定程度上可以设计他们自己的排除适用清单; 经营者无需承担行使反悔权引 起的运费; 即使商品的价值贬损是由检验原因引起, 中国消费者也可能会因 商品不再“完好”而丧失权利。针对上述两大不同, 本书第一章提出的研究假设 可解释第一个不同; 第二个不同则可由经济角度解读: 制造业和出口在中国 社会主义市场经济中起到了更为重要的作用。

第六章以中国法与欧盟法的比较研究结果为基础, 再次检验了第一章所提 出的研究假设。研究结论显示, 管制型市场（在本书语境下指中国市场）往往 倾向于规定更加模糊与抽象的法律规则; 在评价不当行为时, 这些法律规则更 注重实质层面; 在执行这些规则时, 公权力机关扮演了更加核心的角色。竞争 型市场（在本书语境下指欧盟市场）往往倾向于规定更加精确与具体的法律规 则; 在评价不当行为时, 法律规则更注重程序因素; 在一些成员国, 比如德国 与英国, 公力执行的功能与管制型市场相比有一定差距。第六章同时讨论了本 研究存在的不足以及对未来研究的展望和建议。 